\section{タンスの㓣作活動に阅する研究（第2 報）}

一正動会（体高祭）のタンス 中学・高校一 技茶の水好大学 川中茂子

はじめに

運動会（休有祭）のダンスは学校行事の中でも特に大 きな位路を占めておりその連営および指導の如何によつ て，より大きな教育的効果が上がると思う．今回は第 2 報として全国に拁ける実態調査を行い，良い点・難点を 見仙し問題点を取り上げ今啳のより効果的指導につなが ることを用的とする。

\section{調查方法}

炤和 40，41 年度文部省䒠技講習会中学高校ダンス班

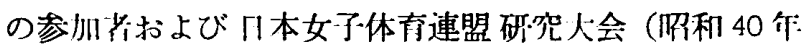
度）の参加者を対象とし質問紙法により回答を求めた。

発送数 346 (回収率 $55.5 \%$ )

\section{結果とその考柰}

本調枿は質開紙法調植であり，内容のわからぬのが難 点である。しかし運動会（体育祭）の施が集尔一同・ 秋に行われ主催も学校・牛徒会が巾心となりダンスを行 らのは好ましいとの絬果が得られた。ダンスの㖽向とし ては作何に「創作」が取りト:げられ「民䠃」も数を增し

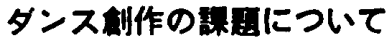

東京女子休青大学○公浦 繁美, 伊沢や急子 田川 典子, 加藤八重子

現在, 学校に抽ける゙ンスのあり方については，色々 と問題にされている。 そこでこの研究を進める第一段 階として，本年は，まず中学校，高等学校に於て，正 課封に括けるダンスの現状を調榃し，把握することを月 啲とし，その参考炕する。調查方法は，筫問紙法に上 り，面和 41 年 7 月〜 9 月までの閒に，東京都の区，市， 郡の 公立中学校 - 高等学校, 私立高等学校を 各二校才゙ つ, 合計 300 校に対して，ダンス指導者宛に郵送し，52 校から回答をえた，調查の結果一ーダンスの時間が足り ないと答之ているのが，全体の53\%を占め，弪立高校が 最も多い，その理由には，運動会の為の指導に，ほ上ん ぞ使われてしまう，学校行标などでつぶれる，他の教材 に，時閣がかかるなどがあげられている。また，十分足 りると答えているのは，わずか $5 \%$ ，その時閒は平岣 32 時間である。授業の月別状況をみると，9月が最も多 く，これは運動会を中心に行われているのがわかる．特 に公立中学校に执いては，それが明らかである，1年閌 （8月を除いて11 カ月）行つている学校が，公立高校で
てきている．しかし運動会（体有祭）は各学校でそれぞ れに意義や目的・形式を異にし，教育的効果の良否は総 命的に判断されなければ簡単に結論は出ないと思う。現 状ではダンスの持つそれぞれの特色を利用して運動会に 参加させ教育的効果をあげているとみる，次に運動会・ 創作活動についての問題点を取りあげてみる.

(1)運動会（体育祭）の目的，性格等を各学校毎に改め て検討寸る必要があるのではないか，従つてそれが確立 されればダンスの取り上げ方，類別および教育的効果を 予測出来，その指導法が考えられる。

(2)高校では生徒会主催が多いのにダンス担当者が学習 発表の場と考えていること．創作に関してここに矛盾が 起こらぬのであろらか.

(3)正課授業時の創作活動と運動会時の創作作品とを同 じ报いでなく多面的に（目的・観鼻・集団・空䦓等）考 える必要がある．授業即運動会の連結には無理な点が多 いここの場介どちらに動きをおくかで内兴とそれに伴な

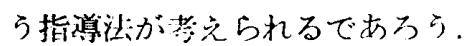

以上の諸点上り第１報上介われ順次上り上き指獐法を 胃忙てて行きたいと考えている。

は1校，私古高校では 4 校及られた。また，公立高校で は，73\%，私立高校では75\%が作閶通して行つた方がよ い之答えている．内容別実施校数の最も高いのは，基本 渾動であり，フォークダンス，創作，表現，参考作品の 順であるが，これを平约配当時間でみると，最も多いの は創作である。ダンス指導上の意見については，中・高 管学校とも，基本渾動の必要吽，中学での経験の差など についての意見が多かつた，以上の調夜を参考に，今後 は，地方の現状を知り，ダンス発展のために研究を進め たい上思ら。

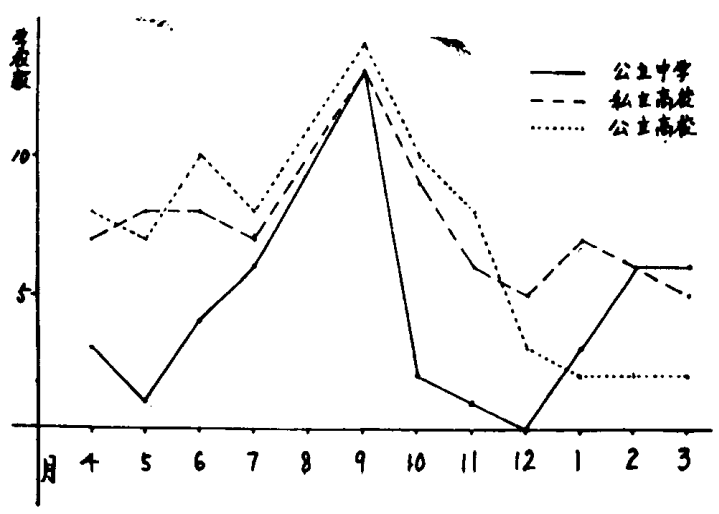

